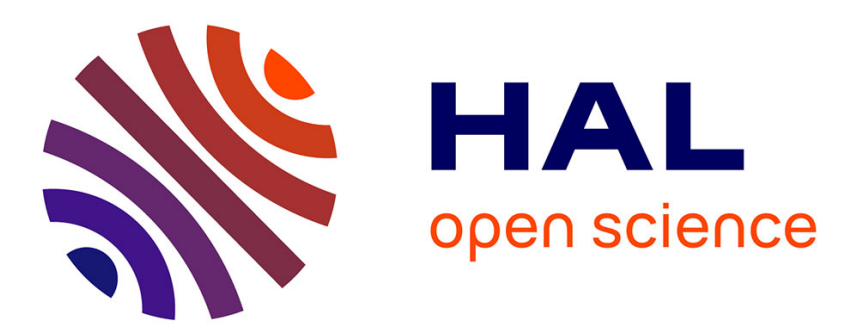

\title{
The presence of shade-intolerant conifers facilitates the regeneration of Quercus petraea in mixed stands
}

Jeremy Borderieux, Yoan Paillet, Marine Dalmasso, Anders Mårell, Thomas

Perot, Patrick Vallet

\section{To cite this version:}

Jeremy Borderieux, Yoan Paillet, Marine Dalmasso, Anders Mårell, Thomas Perot, et al.. The presence of shade-intolerant conifers facilitates the regeneration of Quercus petraea in mixed stands. Forest Ecology and Management, 2021, 491, pp.1-10. 10.1016/j.foreco.2021.119189 . hal-03195682

\section{HAL Id: hal-03195682 \\ https://hal.inrae.fr/hal-03195682}

Submitted on 12 Apr 2021

HAL is a multi-disciplinary open access archive for the deposit and dissemination of scientific research documents, whether they are published or not. The documents may come from teaching and research institutions in France or abroad, or from public or private research centers.
L'archive ouverte pluridisciplinaire HAL, est destinée au dépôt et à la diffusion de documents scientifiques de niveau recherche, publiés ou non, émanant des établissements d'enseignement et de recherche français ou étrangers, des laboratoires publics ou privés. 
This manuscript was published in Forest Ecology and Management in April 2021.

Here is the link to the published article : https://doi.org/10.1016/j.foreco.2021.119189

The presence of shade-intolerant conifers facilitates the regeneration of Quercus petraea in mixed stands

Jeremy BORDERIEUX1, *, Yoan PAILLET ${ }^{1}$, Marine DALMASSO², Anders MÅRELL ${ }^{3}$, Thomas PEROT ${ }^{3}$, Patrick VALLET ${ }^{1}$

1. Univ. Grenoble Alpes, INRAE, LESSEM, 2 rue de la Papeterie-BP 76, F-38402 StMartin-d'Hères, France.

2. IGN, Château des Barres, F-45290 Nogent-sur-Vernisson, France

3. INRAE, EFNO, F-45290 Nogent-sur-Vernisson, France

Corresponding author: Jeremy BORDERIEUX: jeremy.borderieux@agroparistech.fr 


\section{Abstract}

Positive productivity-diversity relationships, pest-effect mitigation and increased resilience and stability maintain an ongoing interest for mixed stands in forestry. However, how mixing species affects forest regeneration is yet to be further explored.

We used data from the French National Forest Inventory (from 2006 to 2016) to model Quercus petraea (Matt.) Liebl regeneration cover in pure and mixed Quercus petraea stands; we included the effects of abiotic and biotic factors as well as mixture. We hypothesized that the characteristics of the companion species would prevent or facilitate the regeneration of oak.

Quercus petraea regeneration cover in this study responded negatively to total canopy cover and herbivory pressure. Mean July potential evapotranspiration (PET), mean December maximal temperature and soil $\mathrm{pH}$ are variables whose spatial variations over a given territory structure regeneration cover; all three of these variables have optimum values. Quercus petraea regeneration cover is linked to the proportion of Quercus petraea in the canopy layer in all mixed stands, except when the oak is mixed with shade-intolerant conifers: in this case, Quercus petraea regeneration is enhanced. The shade tolerance of admixed broadleaved species did not affect the Quercus petraea regeneration. This suggests that oak regeneration was facilitated with a shade-intolerant coniferous companion species due to better light transmittance through the crown or the competitive advantage of Quercus petraea over coniferous shade-intolerant species.

These results are of interest for oak mixtures since Quercus petraea regeneration cover benefits from mixtures with shade-intolerant conifers and is at least equal to that of pure stands.

\section{Keywords}

Regeneration, National Forest Inventory, Quercus petraea, Modelling, Mixed stands, Shade tolerance, Oak ecology 


\section{Introduction}

Oak forests are widespread in the northern temperate ecotone, and are both ecologically and economically important (Bobiec et al., 2018; Johnson et al., 2019). They provide many ecosystem services such as wood production, aesthetic value and watershed protection (Löf et al., 2016). These forests also play a critical role in maintaining biodiversity as they provide habitats in living trees and deadwood and temperature buffering for many endangered insects (Milberg et al., 2016) and bird species (Felton et al., 2016). However, maintaining oaks in the canopy layer to ensure a sufficient supply of masting trees and including natural regeneration in managed forests are challenging aspects. Poor oak regeneration is widespread throughout its distribution area (Bobiec et al., 2018; Götmark, 2007; Kelly, 2002; Löf et al., 2016), and identifying the factors affecting regeneration is not straightforward. As a mid-shade tolerant species, oak suffers from insufficient light in the understory (Götmark, 2007; Kelly, 2002; Larsen and Johnson, 1998) and lacks the ability to compete with more shade-tolerant species during regeneration (Ligot et al., 2013; Van Couwenberghe et al., 2013), even when the canopy is kept open to favor light-demanding species (Muscolo et al., 2014; Van Couwenberghe et al., 2013). Regeneration failures due to high browsing pressure are also well documented in zones with dense herbivore populations (Kelly, 2002; Kuiters and Slim, 2002; Petersson et al., 2019; Ramirez et al., 2018).

There is a growing interest in tree species mixtures in forestry; indeed, mixed forests often offer advantages. For instance, many studies have documented over-yielding: the mixed stand is more productive than the sum of the expected productivity in the corresponding pure stands (Liang et al., 2016). Tree diversity, trait diversity within the community and evenness in the distribution of the species present are all drivers of the over-yielding observed in mixed forests (del Río et al., 2016; Perot and Picard, 2012; Vallet and Pérot, 2011; Zhang et al., 2012). These three factors are especially interesting for increased productivity on poor sites since certain mixtures result in a greater over-yielding effect, in line with the stress gradient hypothesis (Bertness and Callaway, 1994; Jucker et al., 2016; Toïgo et al., 2015a). This effect could be explained by better crown complementarity between adult trees, optimized light interception and the complimentary use of available resources (Forrester, 2014; Jucker et al., 2015; Ligot et al., 2016, p. 20). Mixing tree species also improve forest stability and resilience against extreme events and global changes (Aussenac et al., 2019; DeClerck et al., 2006; Loreau and de Mazancourt, 2013; Thompson et al., 2009). A richer regeneration layer improves resilience and stability if a species is removed (Yachi and Loreau, 1999). Therefore, it is relevant to study the effects of species mixture on regeneration because mixture is a key component of forest resilience. A diverse regeneration is critical to ensure that the properties of mixed stands carry on to the next generation as the composition of the canopy layer 
ultimately depends on human interventions and the composition the regeneration layer (Bobiec et al., 2018; De Lombaerde et al., 2019; Tinya et al., 2019).

Light is one of the primary limiting factors of tree growth in temperate forests. Therefore, shade tolerance should be a useful trait to investigate since it is related to the mechanisms described above; shade-intolerant species in the canopy do not capture as much light as shade-tolerant species since they have narrower crowns, a lower leaf density and are typically found in less dense stands (Aiba and Nakashizuka, 2009; Niinemets, 2010). This could lead to a brighter understory that would increase the abundance and the growth of the regeneration of midshade tolerant and shade-intolerant species. A synthetic trait like shade tolerance is relevant in a diversity-function study because it may help reveal underlying ecological mechanisms and provide a generic explanation of observed effects.

National Forest Inventory (NFI) data offer an interesting way of studying regeneration because they are distributed over time and space and are representative of the forest resource of the territory, and therefore are usually comprised of a large number of plots. We used French NFI data and developed methods to explore the ecological processes driving forest regeneration in northern temperate forests. Our study focused on sessile oak (Quercus petraea (Matt.) Liebl), which accounted for 18\% of the living broadleaved stock in France in 2019 (IGN, 2019). This species is widespread and often grows in mixtures with many different companion species with contrasted shade-tolerance traits. We hypothesized that (1) $Q$. petraea regeneration would increase with the proportion of $Q$. petraea in the canopy layer. This hypothesis is based on the increase of abundance of near seed-bearer $Q$. petraea generate an increase of regenerating $Q$. petraea, and serves as a null hypothesis for hypothesis (2). We next hypothesized that (2) companion species mixed with $Q$. petraea may have a beneficial or a detrimental effect on $Q$. petraea regeneration; and (3) that this beneficial effect would be explained by the shade tolerance of the companion species, with an increase in $Q$. petraea regeneration as the shade tolerance of the companion species decreased.

\section{Materials and methods}

\section{a. General methodology}

We used French National Forest Inventory (NFI) data to study Q. petraea regeneration in pure and mixed stands at the national scale. We aimed to identify the biotic and abiotic environmental factors influencing $Q$. petraea regeneration cover through a regeneration model. We also studied stand mixture effect on $Q$. petraea regeneration: we included a relationship between the proportion of $Q$. petraea in the canopy and its regeneration cover. In order to identify the companion species capable of facilitating or hindering $Q$. petraea 
regeneration, we only chose bispecific mixed stands; we then tested if the identity of the companion species modified the relationship between the proportion of $Q$. petraea in the canopy and $Q$. petraea regeneration cover.

Finally, in order to generalize our results and gain in interpretability, we tested whether or not the shade tolerance of the companion species explained the mixture effect on $Q$. petraea regeneration.

\section{b. NFI sampling and NFI data}

The French National Forest Inventory (NFI) implements systematic sampling based on a $1 \mathrm{~km}$ by $1 \mathrm{~km}$ grid laid across the territory. The data cover a broad set of climatic conditions from oceanic to semi-continental, mean annual temperatures ranging from 5.9 to $13.8{ }^{\circ} \mathrm{C}$, and annual precipitation ranging from 566 to $2125 \mathrm{~mm}$. Since 2005, around 6000 equally dispersed temporary plots on this grid have been surveyed each year. Our dataset was comprised of the information recorded from 2006 to 2016.

On each plot, the free canopy cover (i.e. the part of the canopy that has free access to light) for every tree species present with at least one individual with a diameter at breast height (dbh) above $7.5 \mathrm{~cm}$ is visually assessed within a 25 -meter-radius circle around the plot center. With data from these observations, we calculated the proportion of each species as the free cover of that species in the canopy layer over the total free cover in the canopy layer of the plot (equation 1).

Prop $_{s p_{i}}=\frac{\text { Free Canopy Cover }}{s p_{i}}$

where Prop $_{s p_{i}}$ is the proportion of species $i$, and Free Canopy Cover Sp $_{i}$ is the free canopy cover of species $i$. This data was supplemented with a floristic survey within a 15-meter-radius circle around the plot center. This survey included all herbaceous and shrub species as well as tree saplings $(\mathrm{dbh}<7.5 \mathrm{~cm})$. The abundance of each species was given a value ranging from 0 to 5 with 0 for absence, 1 for a cover between 0 and 5\%, 2 for a cover between 5 and 25\%, 3 for a cover between 25 and 50\%, 4 for a cover between 50 and $75 \%$ and 5 for a cover above $75 \%$.

\section{c. Plot selection}

We selected plots where the proportion of $Q$. petraea $\left(\right.$ Prop $\left._{Q u P e}\right)$ trees with a diameter at breast height over $7.5 \mathrm{~cm}$ (these trees considered by the NFI) was at least $10 \%$. This allowed us to emphasize factors influencing regeneration over factors influencing species distribution, since only plots containing adult $Q$. petraea were included. To test the effect of the companion species on $Q$. petraea regeneration one at a time, only pure and bispecific mixed stands were included in our model. We selected pure Q. petraea stands (with a proportion of $100 \%$ ) and, 
to minimize the effect of trees species other than the main companion species, mixed stands where the sum of the proportion of $Q$. petraea and of the main companion species was at least/above $90 \%$. To minimize the effect of tree species other than the main companion species, we kept only the plots where the proportion of the remaining species was lower than the proportion of each of the two main species in the mixture. In order to guarantee that our final sample was representative of the whole range of $Q$. petraea proportion values, we only retained bispecific mixtures for which the $Q$. petraea cover proportion amplitude of the NFI plots is at least $70 \%$. We removed the plots identified as "temporarily deforested" in the NFI classification because of the lack of reliable cover data. Finally, to ensure a reliable estimation of the mixture effect, we removed the mixtures represented by less than 20 plots. The final dataset was made up of 1767 pure Q. petraea plots, 4899 Q. petraea-broadleaved mixed plots with 11 different broadleaved companion species, and 643 Q. petraea-conifer mixed plots with seven different coniferous companion species (Table 1, Figure A.1).

\section{d. Regeneration cover variable}

We used the NFI floristic survey to calculate our $Q$. petraea regeneration cover variable, defined in this study as the cover proportion of all trees less than $7.5 \mathrm{~cm}$ in diameter at breast height. The NFI classifies regeneration cover with values between 0 and 5 . For our quantitative approach, we transformed this variable with the mean of each cover class, thus obtaining six values of absolute regeneration cover for each plot: $0,0.025,0.125,0.375,0.625$ and 0.875 . Hereafter, RegeCover ${ }_{\text {QuPe }}$ refers to the regeneration cover of $Q$. petraea, which is our response variable. 
Table 1: Mean of environmental and cover variables $12.5 \%$ and $97.5 \%$ quantiles in parentheses) per plot type. Shade tolerance values were provided by Niinemets and Valladares (2006), except for Pinus nigra var corsicana which has no shade tolerance value.

\begin{tabular}{|c|c|c|c|c|c|c|c|}
\hline Plot type & Companion species & $\begin{array}{l}\text { Shade } \\
\text { tolerance }\end{array}$ & $\begin{array}{l}\text { Number of } \\
\text { plots }\end{array}$ & $\begin{array}{l}\text { Annual mean } \\
\text { temperature } \\
\left({ }^{\circ} \mathrm{C}\right)\end{array}$ & $\begin{array}{l}\text { Annual mean } \\
\text { precipitation } \\
(\mathrm{mm})\end{array}$ & $\begin{array}{l}\text { Total } \\
\text { canopy } \\
\text { cover }(\%)\end{array}$ & $\begin{array}{l}\text { Mean } Q . \\
\text { petraea } \\
\text { proportion }\end{array}$ \\
\hline $\begin{array}{l}\text { Q. petraea } \\
\text { pure }\end{array}$ & & & 1767 & $\begin{array}{l}11 \\
(9.3-12.8)\end{array}$ & $\begin{array}{l}824 \\
(629-1278)\end{array}$ & $\begin{array}{l}85 \\
(27-100)\end{array}$ & 1 \\
\hline \multirow{11}{*}{$\begin{array}{l}\text { Q. petraea - } \\
\text { broadleaved } \\
\text { species }\end{array}$} & Fagus sylvatica (Fa.sy) & 4.56 & 1889 & \multirow{11}{*}{$\begin{array}{l}10.6 \\
(9-12.5)\end{array}$} & \multirow{11}{*}{$\begin{array}{l}913 \\
(649-1404)\end{array}$} & \multirow{11}{*}{$\begin{array}{l}85 \\
(40-100)\end{array}$} & \multirow{11}{*}{$\begin{array}{l}0.57 \\
(0.1-0.9)\end{array}$} \\
\hline & Carpinus betulus (Ca.be) & 3.97 & 1128 & & & & \\
\hline & Quercus robur (Qu.ro) & 2.45 & 766 & & & & \\
\hline & Castanea sativa (Ca.sa) & 3.15 & 470 & & & & \\
\hline & Betula sp (Be.sp) & 1.94 & 246 & & & & \\
\hline & Quercus pubescens (Qu.pu) & 2.31 & 142 & & & & \\
\hline & Fraxinus sp (Fr.sp) & 2.66 & 112 & & & & \\
\hline & Populus tremula (Po.tr) & 2.22 & 50 & & & & \\
\hline & Prunus sp (Pr.sp) & 3.33 & 37 & & & & \\
\hline & Tilia sp (Ti.sp) & 3.93 & 31 & & & & \\
\hline & Robinia pseudoacacia (Ro.ps) & 1.72 & 28 & & & & \\
\hline \multirow{7}{*}{$\begin{array}{l}\text { Q. petraea - } \\
\text { coniferous } \\
\text { species }\end{array}$} & Pinus sylvestris (Pi.sy) & 1.67 & 347 & \multirow{7}{*}{$\begin{array}{l}10.5 \\
(8.4-12)\end{array}$} & \multirow{7}{*}{$\begin{array}{l}893 \\
(654-1494)\end{array}$} & \multirow{7}{*}{$\begin{array}{l}83 \\
(40-100)\end{array}$} & \multirow{7}{*}{$\begin{array}{l}0.47 \\
(0.1-0.9)\end{array}$} \\
\hline & $\begin{array}{l}\text { Pseudotsuga menziesii } \\
\text { (Ps.me) }\end{array}$ & 2.78 & 77 & & & & \\
\hline & Abies alba (Ab.al) & 4.60 & 72 & & & & \\
\hline & Pinus pinaster (Pi.pi) & 1.89 & 54 & & & & \\
\hline & Picea abies (Pi.ab) & 4.45 & 40 & & & & \\
\hline & Pinus nigra nigra (Pi.ni) & 2.10 & 33 & & & & \\
\hline & $\begin{array}{l}\text { Pinus nigra var corsicana } \\
\text { (Pi.co) }\end{array}$ & $x$ & 20 & & & & \\
\hline
\end{tabular}




\section{e. Covariables}

\section{i. Stand and cover variables}

We computed the total canopy cover by summing all the free cover from a given plot. The NFI provides topographic variables such as plot aspect, the steepest slope in the plot and the type, depth and percentage of rocks in the soil. The NFI also provides a classification of the vertical structure of the stand based on a visual estimate (this was also the variable used to define deforested plots i.e. when the vertical structure is lacking) and mentions if a cut has occurred in the last 5 years.

\section{ii. Climate variables}

We used the 30-year climatic values for the period 1981-2010 from the AURHELY Météo France spatial layer to obtain monthly mean, minimum and maximum temperatures $\left(T\right.$, in $\left.{ }^{\circ} \mathrm{C}\right)$ and precipitation (PPT, in $\mathrm{mm}$ ). We derived monthly potential evapotranspiration from these variables (Piedallu et al., 2013; Piedallu and Gégout, 2007).

\section{iii. Soil, floristic and bio-indication variables}

We estimated soil water holding capacity (SWHC, in $\mathrm{mm}$ ) for all the plots from soil texture, percentage of rock and soil depth (Piedallu et al., 2018). We used the floristic survey to infer acidity $(\mathrm{pH})$, carbon to nitrogen ratio $(\mathrm{C}: \mathrm{N})$ of the soil organic matter and the base saturation (S:T) of the first layer of the soil by averaging indicator values of each present species (Gégout et al., 2005). The floristic survey was also used to estimate regeneration inhibition by three competitive plants: Rubus fruticosus, Molinia caerulea and Pteridium aquilinum; we created 3 Boolean variables when their respective absolute cover was more than $50 \%$.

\section{iv. Herbivory pressure proxy}

In order to obtain a proxy for the pressure exerted by herbivores on $Q$. petraea acorns, seedlings and saplings, we used district-level hunting statistics provided by the French Office of Biodiversity (OFB). A yearly ungulate pressure index was calculated by district from i) hunting bag statistics of Sus scrofa, Capreolus capreolus and Cervus elaphus; ii) their respective basal metabolic rates estimated from the mean body mass of the species to the power of 0.75 (Clarke et al., 2010; Petersson et al., 2019; White and Seymour, 2005); and iii) the surface of the district, the calculation is summarized in equation (2).

Herbivory index $x_{c}=\frac{\sum_{j} n_{j c^{*} m_{j}^{0.75}}}{\text { Area }_{c}}(2)$

Where $n_{j c}$ is the number of species $j$ killed in the district $c, m_{j}$ is the mean mass of the species $j$, and $\mathrm{Area}_{c}$ is the area of the district $c$ (Petersson et al., 2019). The resulting index was then smoothed with a 3-year moving averaging to reduce inter-annual variability and because we did not know which year the saplings had been browsed. 


\section{v. Shade tolerance data}

Values for shade tolerance, from 1 (shade intolerant) to 5 (shade tolerant) of the tree species, were provided by Niinemets and Valladares (2006).

\section{f. Modelling framework}

Regeneration cover values are constrained between 0 and 1 ; we therefore modelled them with a logistic model (Wright, 1995). We multiplied this function by a reducer in order to take into account the proportion of Quercus petraea in the stand. Without the companion species interaction, this reducer gave a decrease proportional to $Q$. petraea proportion in the stand: a mixed stand with $50 \%$ Q. petraea would have $50 \%$ less regeneration than a pure stand with the same environmental conditions. We chose this linear relationship for its robustness, after carrying out a scatter plot analysis. Finally, an estimated species-specific parameter was included in the reducer to allow us to modify the slope of the linear relationship for mixed stands depending on the companion species.

Equation (3) describes this model:

RegeCover $_{\text {QuPe }}=F_{1}\left(X_{n}\right) * F_{2}\left(\right.$ Prop $\left._{\text {QuPe }} S P_{i}\right)(3)$

where $F 1$ is a logistic model, depending on the environmental variable $X_{n}, F 2$ is the mixture reducer function, Prop $_{Q u P e}$ is the proportion of Quercus petraea in the canopy, and $S P_{i}$ is a dummy variable set to 1 only when the companion species of Q.petraea was species $i$.

The full expression of the model is written as:

RegeCover $_{\text {QuPe }}=\left(\frac{1}{1-e^{-\left(\beta_{0}+\Sigma_{n} \beta_{n} \times X_{n}\right)}}\right) \times\left(1-\left(1-\operatorname{Prop}_{\text {QuPe }}\right) \times \max \left(0,\left(\sum_{i} S P_{i} \times\left(1-a_{i}\right)\right)\right)\right)+\varepsilon(4)$

where $\beta_{n}$ and $a_{i}$ are fitted parameters. In equation (4), $\left(1-\right.$ Prop $\left._{Q u P e}\right)$ represents the proportion of the companion species. We then multiplied $\left(1-\operatorname{Prop}_{Q u P e}\right)$ by $\left(1-a_{i}\right)$ to express the effect of the companion species and to make it possible to test the significance of the effect: if $a_{i}$ is not significantly different from 0 , the reducer acts as a proportional relationship between regeneration and Quercus petraea proportion. This formulation resulted in a model that could include both pure and mixed stands, which allowed us to fit the model on all the selected plots at once. As the reducer is linear, we added the function "max" so that the model would not produce negative values, and would instead show no regeneration.

The term $\varepsilon$ represents the residual errors, following a Gaussian distribution with a mean of 0 and a variance $\sigma^{2}$. Regeneration cover data displayed heteroscedasticity when plotted against total cover and $Q$. petraea proportion. We therefore applied a power variance model to these two variables in order to take this heteroscedasticity into account (Pinheiro and Bates, 2000). The structure of our cover data was unbalanced, both in terms of the distribution of the different cover categories and the range of cover included in these categories. Consequently, $\varepsilon$ 
displayed a slightly asymmetric distribution, but which we considered to be within a normal range and therefore ignored.

To ensure better robustness and biologically accuracy, we included the environmental variables in three different forms: linear, quadratic and one with exponential decay. We scaled all the quantitative environmental variables in order to simplify the fitting procedure and to obtain comparable parameter estimates.

We selected the environmental variables following an ascending stepwise AIC procedure. In order to select the most parsimonious model, a variable is kept in the model only if it decreases the AIC (Akaike Information Criterion) by at least 2 points with a linear form, or 4 points with quadratic or exponential-decay forms because they have 2 parameters (Akaike, 1974; Burnham and Anderson, 2002). To avoid collinearity between environmental variables, we excluded any variable from the procedure when its Spearman correlation coefficient with a previously selected variable exceeded 0.4 .

\section{i. $\quad$ Shade tolerance model}

Once we had fitted the full model in equation (4), we used the shade tolerance values of the companion species to test whether shade tolerance structured the estimated species-specific parameters. We used a linear model for that purpose, as described in equation (5):

$a_{i}=s_{0}+s_{1} *$ Tolerance $_{i}+\varepsilon(5)$

where $a_{i}$ are the estimated species-specific parameters fitted in equation (4), Tolerance $_{i}$ is the tolerance of the companion species, and $s_{0}$ and $s_{1}$ are the parameters of the model. The model was fitted separately for coniferous and broadleaved companion species. We excluded Pinus nigra var. corsicana because we lacked the shade tolerance value for this species. $\varepsilon$ represents the Gaussian errors with a mean of 0 and variance $\sigma^{2}$. Because species-specific parameters are not estimated with the same precision when fitting equation (4), this variance is weighted by the inverse of the squared standard error of the estimated parameters in order to give more weight to the most accurate parameters.

\section{ii. Statistical procedures}

We analyzed the data with the R software 3.6.2 (R Core Team, 2019). We fitted the model in equation (4) with the gnls function of the R package 'nlme' according to the generalized least squares method (Pinheiro et al., 2017). We fitted the second model, presented in equation (5), with a linear weighted model. The normalized residuals of the regeneration model in equation (4) were plotted against every variable as well as with the $X$ and $Y$ coordinates, and no patterns diverging from the 0 axis were found. 


\section{Results}

\section{a. Q. petraea regeneration}

Overall, we observed the presence of $Q$. petraea regeneration in $67 \%$ of our plots. Regeneration presence varied among plot types: $75 \%, 64 \%$ and $72 \%$ respectively of pure, mixed $Q$. petraea-broadleaved companion species and mixed $Q$. petraea-coniferous companion species stands displayed $Q$. petraea regeneration. The mean $Q$. petraea regeneration cover was $14.5 \%$ in pure stands, $7.3 \%$ in mixed $Q$. petraea-broadleaved stands and $9.1 \%$ in mixed $Q$. petraea-coniferous stands, and varied with companion species (Figure 1). Mean regeneration cover displayed high variability, with a coefficient of variation of $180 \%$.

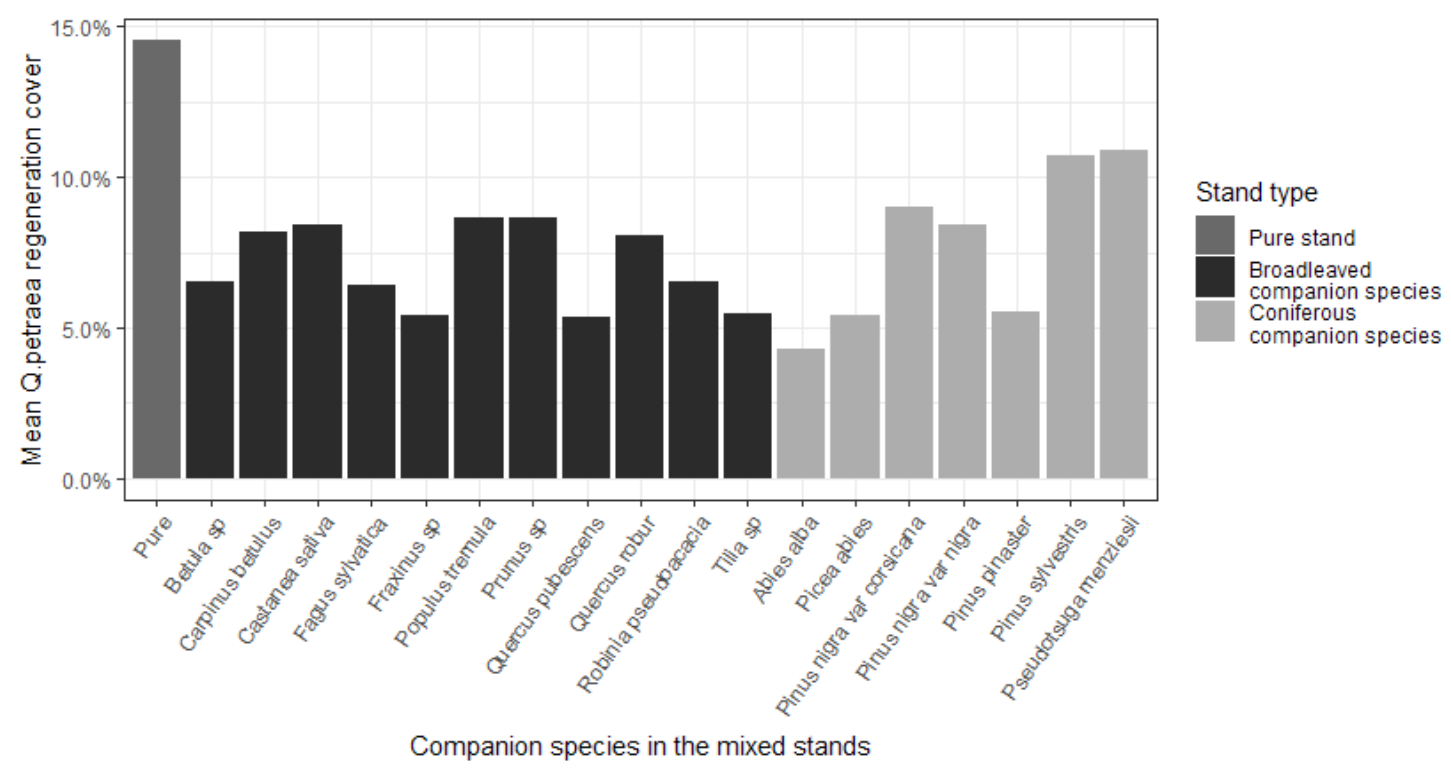

Figure 1: Mean $Q$. petraea regeneration cover as a function of the companion species in the mixed $Q$. petraea stands.

\section{b. Estimated parameters of the regeneration model}

In our model, 11 environmental variables explain the regeneration cover of Quercus petraea (Table 2). Regeneration cover decreases with increasing total canopy cover of the stand (Figure A.2, A), and to a lesser extent, is higher in coppice-with-standards stands. The presence of an absolute cover of Molinia caerulea equal to or greater than $50 \%$ had a negative effect on $Q$. petraea regeneration, but with a p-value only significant at the $10 \%$ type- 1 error threshold.

The best fitting form for the herbivory index was exponential decay. The negative effect on regeneration of an herbivory index between 0 and 50 (the mean value of the index) was drastic with regeneration cover divided by two over this interval, but the effect stabilized after that (Figure A.2, B). 
The other selected parameters are associated with bio-geo-climatic variables: $\mathrm{PET}_{7}$ (Mean evapotranspiration potential in July), $\operatorname{Tmax}_{12}$ (mean December maximal temperature) and the bio-indicated soil $\mathrm{pH}$. These three variables all had a quadratic form, with an optimum occurring within the range of values, i.e. a $\mathrm{PET}_{7}$ of $134 \mathrm{~mm}$, a $\operatorname{Tmax}_{12}$ of $5.9^{\circ} \mathrm{C}$ and a $\mathrm{pH}$ of 4.7 (Figure A.2, C, D, E). The presence of a carbonated soil, the percentage of rocky outcrop and Northern exposure and Eastern exposure had a slightly negative effect in terms of magnitude on $Q$. petraea regeneration cover via a simple linear relationship (Table 2).

The species-specific parameters of the Corsican pine (Pinus nigra var corsicana), Scots pine (Pinus sylvestris), maritime pine (Pinus pinaster), Douglas fir (Pseudotsuga menziesii) and chestnut (Castanea sativa) were significantly positive. This result implies that the relationship between $Q$. petraea regeneration cover and the proportion of $Q$. petraea in the canopy was more beneficial to regeneration than a proportional relationship in mixed stands with these companion species (Figure 2). No companion species had a significantly negative speciesspecific parameter thus no companion species had a detrimental effect on $Q$. petraea regeneration.

Table 2: Coefficients (Estimate), standard errors (Std.error) and p-values of the estimated parameters in the selected regeneration model. The variables associated with environmental function parameters are all scaled except for the Boolean variables (Coppice-with-standards stand, Molinia caerulea, Soil $c_{\text {caronated }}$, and the companion species variables). Significant companion species parameters are in bold. Means, standard deviations and ranges for the continuous variables are available in Table A.1. For a detailed explanation of the form associated with the environmental variables, see Table A.1. For a representation of the response curves of the continuous variables, see Figure A.2.

\begin{tabular}{|c|c|c|c|c|}
\hline & Variable & Estimate & $\begin{array}{l}\text { Std. } \\
\text { Error }\end{array}$ & p-value \\
\hline \multirow{10}{*}{$\begin{array}{l}\text { F1 part of the model: } \\
\text { environmental } \\
\text { variables }\end{array}$} & Intercept & -1.97 & 0.0693 & $<10^{-4}$ \\
\hline & Total canopy cover & -0.0624 & 0.0322 & 0.052 \\
\hline & Total canopy cover ${ }^{2}$ & 0.0608 & 0.0111 & $<10^{-4}$ \\
\hline & $\begin{array}{l}\text { Coppice with standards } \\
\text { stand }\end{array}$ & 0.18 & 0.0435 & $<10^{-4}$ \\
\hline & Molinia caerulea & -0.311 & 0.162 & 0.055 \\
\hline & Herbivory index & 0.117 & 0.0472 & 0.013 \\
\hline & Herbivory index & -1.67 & 0.313 & $<10^{-4}$ \\
\hline & $\mathrm{PET}_{7}$ & 0.463 & 0.0327 & $<10^{-4}$ \\
\hline & $\mathrm{PET}_{7}{ }^{2}$ & -0.159 & 0.0215 & $<10^{-4}$ \\
\hline & $\operatorname{Tmax}_{12}$ & -0.2 & 0.0315 & $<10^{-4}$ \\
\hline
\end{tabular}




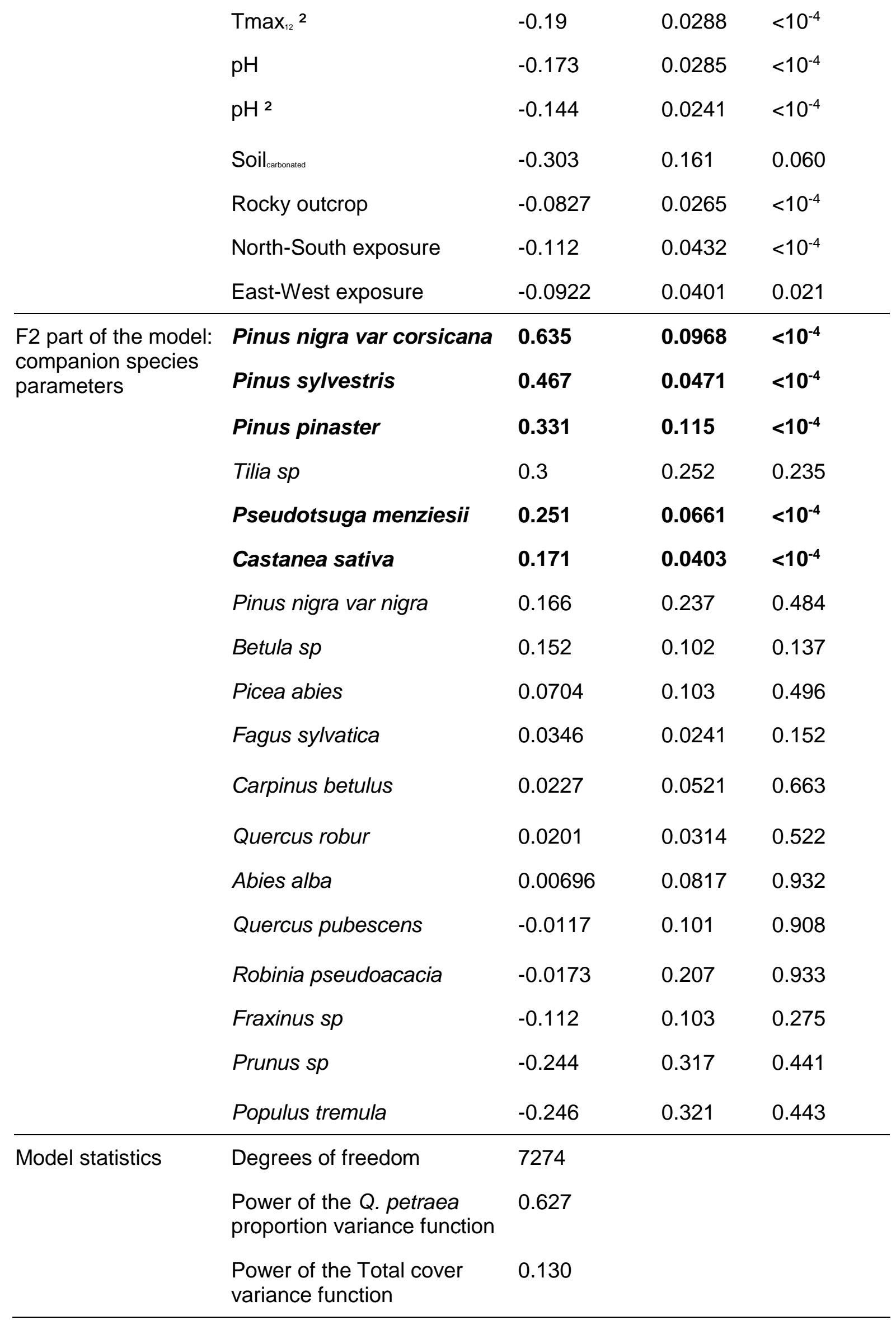




\section{c. Mixture effect on regeneration as a function of the companion species}

We used the values of these species-specific parameters (Table 2) to predict how mixture would affect $Q$. petraea regeneration cover for each companion species mixed with $Q$. petraea. When a species-specific parameter is non-significant, the relationship between $Q$. petraea regeneration and $Q$. petraea proportion is close to a proportional relationship (Figure 2). However, for Pinus nigra var corsicana, Pinus sylvestris, Pinus pinaster, Pseudotsuga menziesii and Castanea sativa, which had positively significant parameters, mixed stands with these species and a canopy proportion of $50 \%$ Q. petraea respectively displayed $81 \%, 73 \%$, $67 \%, 63 \%$ and $59 \%$ of the regeneration cover in a pure Q. petraea stand with the same environmental conditions (Figure 2).

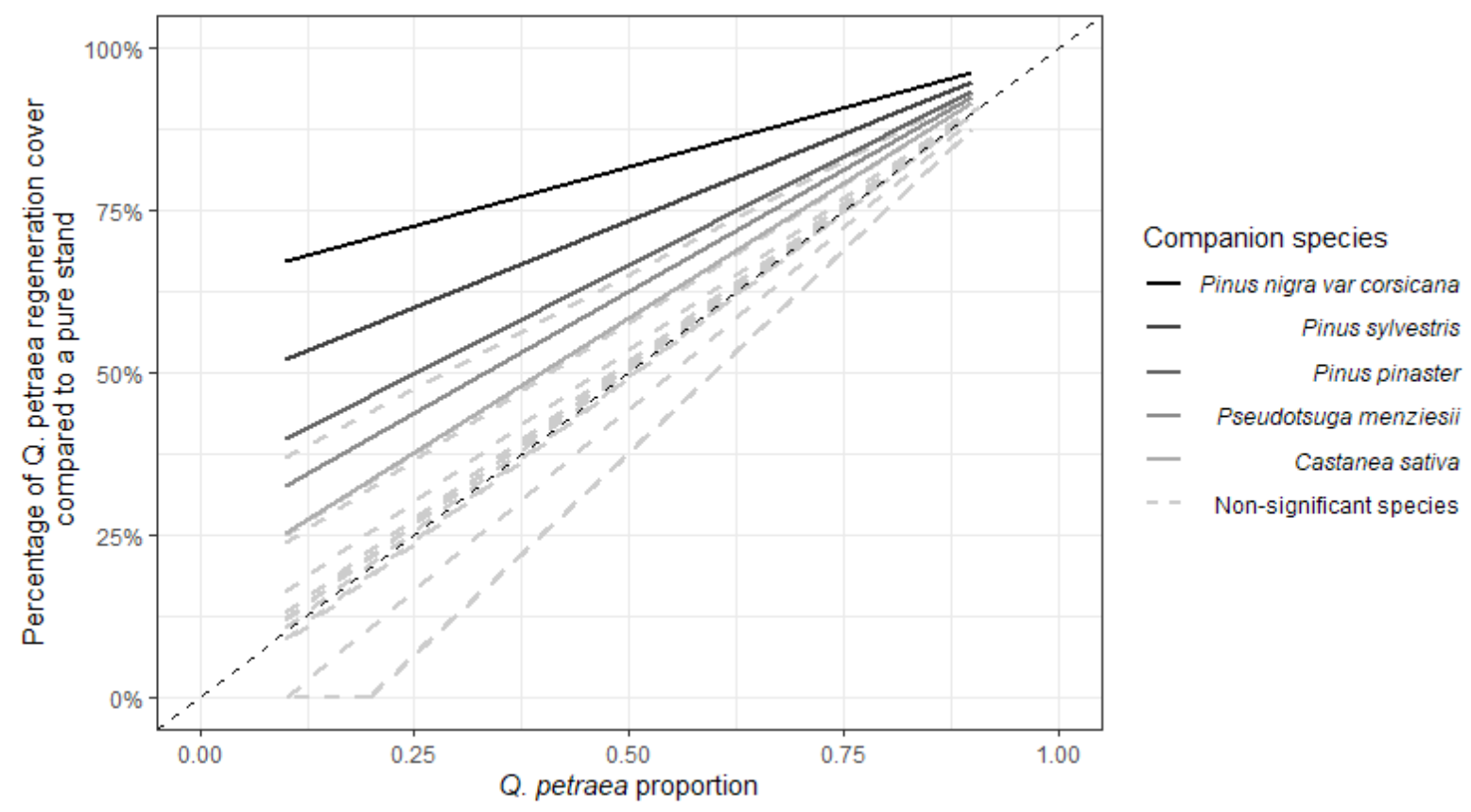

Figure 2: Percentage of $Q$. petraea regeneration cover in a mixed stand compared to a pure stand in the same environmental conditions as a function of companion species identity and Q. petraea canopy proportion, according to the regeneration model (i.e. the value of the reducer function F2). Solid lines represent the species with significant species-specific parameters. The segments stop at the minimal and maximal $Q$. petraea proportion observed in the dataset for each companion species.

\section{d. Mixture effect as a function of companion-species shade tolerance}

The linear model for the coniferous companion species $\left(p\right.$-value $\left.<10^{-4}, R^{2}=0.941\right)$ detected a significant relationship between the value of the species-specific parameter described in Table 2 and the shade tolerance of the associated companion species; this was not the case for the broadleaved companion species (Table 3, Figure 3). 
Table 3: Estimates, standard errors and p-values of the estimated parameters, and the $R^{2}$ of the linear regression presented in equation (5). We fitted the model for the coniferous and the broadleaved companion species separately.

\begin{tabular}{lllll}
\hline Coniferous companions & Estimate & Std. Error & $\mathbf{p}$-value & $\mathbf{R}^{\mathbf{2}}$ \\
\hline Intercept & 0.686 & 0.0531 & $<10^{-4}$ & \\
Shade tolerance & -0.147 & 0.0185 & $<10^{-4}$ & 0.941 \\
\hline Broadleaved companions & Estimate & Std. Error & $\mathbf{p}$-value & $\mathbf{R}^{\mathbf{2}}$ \\
\hline Intercept & 0.0603 & 0.0839 & 0.491 & \\
Shade tolerance & -0.00341 & 0.0228 & 0.884 & 0.00251 \\
\hline
\end{tabular}

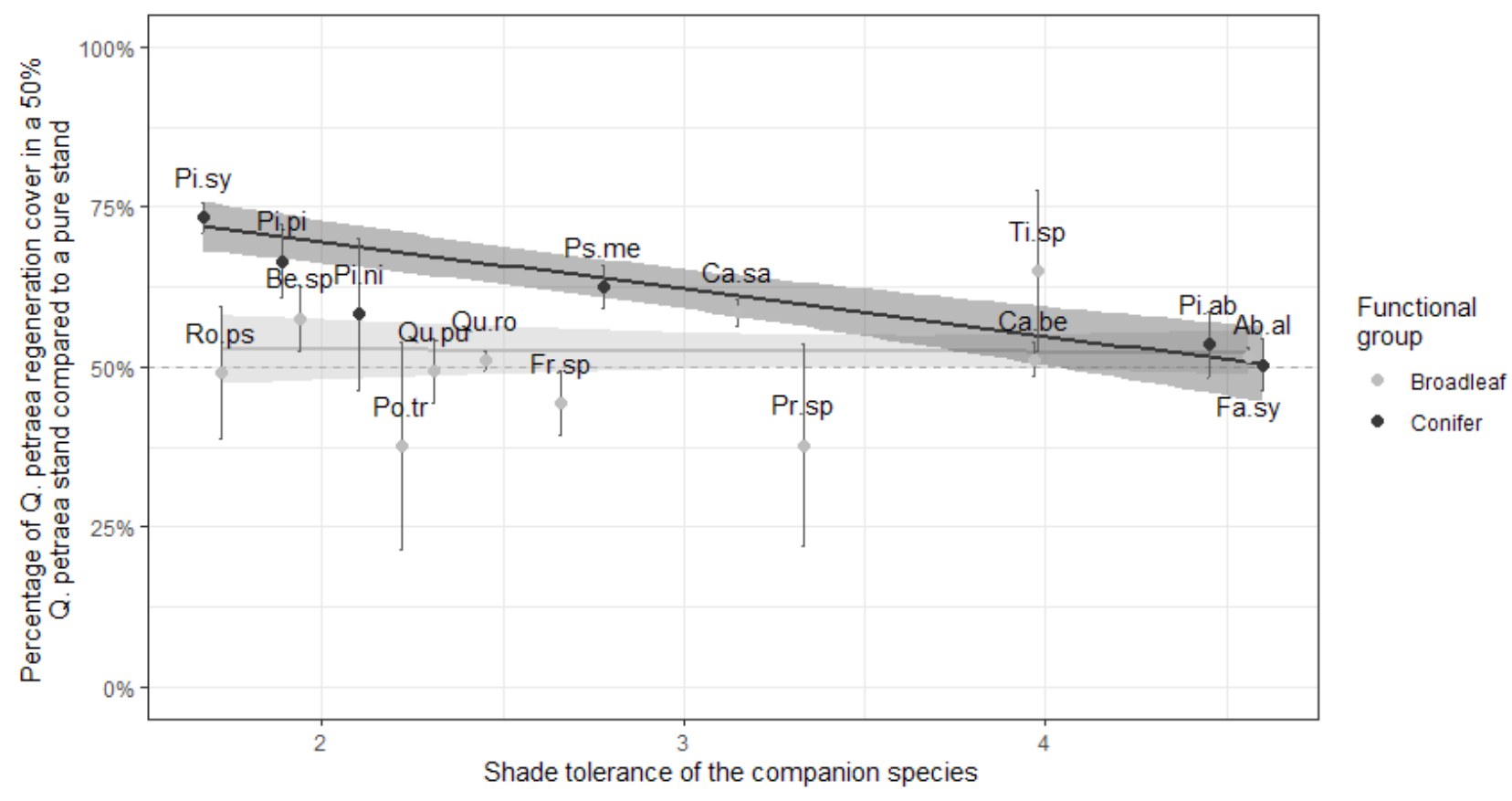

Figure 3: Proportion of $Q$. petraea regeneration cover in a 50\%-50\% mixed stand compared to a pure stand as a function of companion-species shade tolerance and functional group, according to the regeneration model (i.e. the value of the reducer function $F 2$ at $50 \% Q$. petraea proportion). The vertical segment shows the prediction \pm the standard error of the associated parameter from Table 2. The linear shade tolerance model for each of the two functional groups is represented by a straight line, while the shaded ribbon shows the confidence interval. Abbreviations for companion species are given in Table 1. Pinus nigra var corsicana is not shown because its shade-tolerance value was lacking. 


\section{Discussion}

To study the influence of environmental factors and species mixture on $Q$. petraea regeneration at the national scale, we built a regeneration model based on French NFI regeneration and cover data that explicitly considered both of these effects. The selected environmental factors allowed us to compare the mixtures independently of environmental conditions and also provided us with interpretable ecological variables. The species mixture part of the model revealed mixtures where $Q$. petraea regeneration was higher than expected; this effect concerned shade-intolerant coniferous companion species only.

\section{a. Biotic and abiotic environmental drivers of $Q$. petraea regeneration}

As for many intermediate shade-tolerant species, light condition plays a major role in $Q$. petraea regeneration. Our results confirmed previous findings since, in our study, total canopy cover was negatively correlated with Q. petraea regeneration cover (Ádám et al., 2013; Annighöfer et al., 2015; Jarvis, 1964; Larsen and Johnson, 1998). However, the relationship between total canopy cover and regeneration was not linear: first, a drastic decrease occurred between 0 and $50 \%$ total canopy cover, then the curve stabilized. This may be due to the ability of $Q$. petraea to adapt its light acquisition strategy, to a certain extent, when growing in heavy shade, by allocating more carbon and resources to leaf and shoot development (Jarvis, 1964; Larsen and Johnson, 1998; Rodríguez-Calcerrada et al., 2008). We can interpret the positive effect of 'coppice-with-standards stand' (a vertical structure variable) as an extension of this interpretation, since vertical heterogeneity can increase light availability and light heterogeneity. This relationship is still unclear, however, because the variable also depends on heterogeneity in stand composition and diameter at breast height (Ligot et al., 2016).

The presence of an important Molinia caerulea cover was the only understory variable the model identified, but magnitude and significance were low. This was surprising since some understory species can have a significant influence on regeneration via competition for light and soil water and nutrient resources. The effect of competitive vegetation on regeneration interacts with many environmental variables, for example, light availability and site productivity, which affect both regeneration and the diversity and cover of competitive vegetation (De Lombaerde et al., 2019; Gaudio et al., 2011; Ward et al., 2018). These effects are hard to disentangle for a large plot sample like ours. Indeed, clearly identifying vegetation interference variables will require dedicated plot selection and analysis and an understanding of the environmental factors affecting both regeneration and competitive vegetation.

Q. petraea saplings are subject to browsing by ungulates, sometimes to the point where regeneration can be compromised. Our results support these findings since $Q$. petraea regeneration cover was negatively linked to our herbivory index, exponentially decreasing with 
increasing herbivory (Kelly, 2002; Kuiters and Slim, 2002; Petersson et al., 2019). The regeneration cover we modelled mostly consisted of $Q$. petraea saplings, and deer have a larger impact on already established saplings by browsing their leaves and shoots, especially the newly-grown, more palatable ones; this limits overall sapling growth and competitiveness, acorns could also be predated by wild boars, thus reducing regeneration (Götmark et al., 2005; Mårell et al., 2018; Ramirez et al., 2018).

It should be noted, however, that we calculated our herbivory index at the district scale. Therefore, our index does not accurately represent the spatial heterogeneity of the actual browsing pressure. Browsing effect on regeneration would be more accurately assessed with finer scale data, and by including interactions among other factors: for example, the presence or absence of other palatable species (Jensen et al., 2012), the presence of deadwood acting as a physical barrier (Borkowski et al., 2017; Hagge et al., 2019), interactions with humans (Miller et al., 2009), the distance to the closest forest edge and, of course, trees species in the mixture (Bernard et al., 2017; Boulanger et al., 2009), as was the case in our study.

Bio-geo-climatic variables can encompass many processes. The two selected variables, mean July PET and mean December maximum temperature, were mean values over 30 years. Therefore, they provide spatial information on $Q$. petraea regeneration distribution and preferences. The increase in $Q$. petraea regeneration with July PET up to the optimum peak can be attributed to more light availability (as solar radiation is included in PET calculations) and warmer and more productive forests, while the decrease after the optimum peak can be linked to an insufficient water balance and a higher probability of drought (Piedallu and Gégout, 2007). Soil pH was also an explanatory variable, with a concave-shaped response curve that reached its optimum at 4.8. This result corroborates the findings of other authors, who set the optimum $\mathrm{pH}$ for even-aged $Q$. petraea stands from acidic to neutral soils (Bergès et al., 2005). Following this reasoning, our negative results for carbonated soil seem logical.

\section{b. Companion species effect on $Q$. petraea regeneration in mixed stands}

We showed that $Q$. petraea proportion had a proportional relationship with $Q$. petraea regeneration cover, and that this relationship could be modified in a mixed stand with certain companion species. Previous regeneration studies had positively linked oak regeneration to the proportion of adult oaks in the overstory; oak dispersal capacity is low, resulting in higher sapling and acorn density near adult oaks (Ádám et al., 2013; Annighöfer et al., 2015; Battaglia et al., 2008; Fei and Steiner, 2008; Tinya et al., 2019). We therefore used the simple proportional relationship as our null hypothesis to test for a companion-species effect on $Q$. petraea regeneration. We found that the relationship was modified and that certain companion species had a positive effect on oak regeneration. This was the case for the following companion species: Pinus nigra var corsicana, Pinus sylvestris, Pinus pinaster, Pseudotsuga 
menziesii and Castanea sativa. We also demonstrated that the shade tolerance value of the coniferous companion species structured the extent of the positive effect on $Q$. petraea regeneration but that this effect was not detected for the broadleaved companion. We also noted that no companion had any detrimental effect on $Q$. petraea regeneration cover, regardless of the species; we observed satisfactory $Q$. petraea regeneration in every mixed stand. This lack of a negative effect on regeneration added to the positive effects mixture is known to have on mature stands (see Introduction) leads to an overall positive effect. This was surprising since species like the shade tolerant beech Fagus sylvatica can outcompete and outgrow oaks (Ligot et al., 2013; Van Couwenberghe et al., 2013). There are two possible explanations for this lack of detrimental effect for Fagus sylvatica. First, our data did not reflect the vertical stratification, growth and vigor of the regeneration; therefore, Q. petraea regeneration was recorded even if $F$. sylvatica trees might potentially outcompete the oak regeneration as the stand aged. Second, foresters tend to eliminate $F$. sylvatica saplings to promote oak saplings, and observational data such as those provided by the NFI do not take this into account.

The beneficial effect on regeneration of several shade-intolerant coniferous companion species suggests better light transmission through the crown of the companion species. This is especially relevant in situations where the canopy is closed or nearly closed. Shadeintolerant species have a less optimized crown architecture (narrower and a less dense) in terms of light interception (Aiba and Nakashizuka, 2009) than do shade-tolerant species since they grow faster and higher. Trees exhibiting this architecture have higher light transmittance, leading to a brighter environment in the regeneration layer, Pinus species, that are preponderant in the significant companion species we found, are a notable example of this particular crown architecture (Ligot et al., 2013, p. 200; Messier et al., 1998; Perot et al., 2017). In mixed stands, especially with shade-intolerant species, understory light and light heterogeneity are enhanced (Ligot et al., 2016; Messier et al., 1998). We only identified a significant effect for coniferous, not broadleaved, companion species. This may be because the effect of broadleaved species in mixtures is also smaller with productivity (Toïgo et al., 2018), and may have been impossible to detect with our data.

Furthermore, conifers and broadleaves with the same shade tolerance still differ greatly in crown shape and other traits that could explain the difference in significance of effect on regeneration we found between the two functional groups (Pretzsch and Schütze, 2009). For example, broadleaves are known to have more crown plasticity than conifers; they will often more efficiently fill canopy gaps between adult trees, leading to a darker understory environment (Jucker et al., 2015; Purves et al., 2007). Other significant relationships could also be involved. For example, belowground interactions and root system complimentary may decrease intra- or interspecific competition for a limited water supply, thus resulting in a 
positive effect of certain mixtures. A drought tolerant companion species could also reduce the overall water demand of the stand, thus leaving more water and a wetter soil for oak seedlings and saplings (Forrester, 2014).

The positive effect on oak regeneration we identified in mixtures with coniferous shadeintolerant species may also be explained by competition in the regeneration layer. Shadetolerant species can grow even in heavy shade, meaning they will eventually outcompete $Q$. petraea by capturing the available light in the understory. Conversely, a shade-intolerant companion species will cast less shade, thus enabling $Q$. petraea to better compete for the available light and to grow taller than the saplings of the companion species, thus reducing the light available to them and inhibiting their further growth (De Lombaerde et al., 2019; Klopčič et al., 2015; Leuschner et al., 2001; Ligot et al., 2013). However, this effect is hard to investigate with French NFI data because each plot survey is unique (the plots are not permanent), so no temporal data is available to study relative growth and competition among saplings. Moreover, NFI cover data does not include a vertical classification, only absolute cover.

\section{Conclusion}

We identified several environmental variables influencing $Q$. petraea regeneration in accordance with the current knowledge of $Q$. petraea ecology. By including them in our model, we were able to estimate the companion-species effect independently from environmental conditions. Four out of seven coniferous companion species (Corsican pine, Scots pine, maritime pine, Douglas fir) and one out of eleven broadleaved companion species (chestnut) had a positive effect on $Q$. petraea regeneration. No companion species had a negative effect. For the coniferous companions, their positive effect on oak regeneration was strongly correlated with their level of shade tolerance; no such correlation was found for the broadleaved companion species.

Mixed stands present numerous advantages, such as significantly increased productivity on naturally less productive sites and enhanced resilience to global changes (DeClerck et al., 2006; Toïgo et al., 2015a, 2015b). However, ensuring the regeneration of the overstory species in mixed stands can be challenging since the co-occurring species differ in tolerance levels and ecological preferences. Our results imply that the companion species can have a significant positive effect on regeneration. Future studies on regeneration in mixed stands should assess the regeneration of both species in the mixture to account for competitive interactions between the regenerating species; for example, regenerating pine in a mixture can be very difficult due to its shade intolerance. 


\section{Acknowledgements}

The French National Forest Office funded this work. The authors are grateful to the NGI (French National Geographic Institute) for providing the French NFI data and to Vicki Moore for correcting the English.

\section{References}

Ádám, R., Ódor, P., Bölöni, J., 2013. The effects of stand characteristics on the understory vegetation in Quercus petraea and Q. cerris dominated forests. Community Ecol. 14, 101-109. https://doi.org/10.1556/ComEc.14.2013.1.11

Aiba, M., Nakashizuka, T., 2009. Architectural differences associated with adult stature and wood density in 30 temperate tree species. Funct. Ecol. 23, 265-273. https://doi.org/10.1111/j.1365-2435.2008.01500.x

Akaike, H., 1974. A new look at the statistical model identification. IEEE Trans. Autom. Control 19, 716-723. https://doi.org/10.1109/TAC.1974.1100705

Annighöfer, P., Beckschäfer, P., Vor, T., Ammer, C., 2015. Regeneration Patterns of European Oak Species (Quercus petraea (Matt.) Liebl., Quercus robur L.) in Dependence of Environment and Neighborhood. PLoS ONE 10. https://doi.org/10.1371/journal.pone.0134935

Aussenac, R., Bergeron, Y., Gravel, D., Drobyshev, I., 2019. Interactions among trees: A key element in the stabilising effect of species diversity on forest growth. Funct. Ecol. 33, 360-367. https://doi.org/10.1111/1365-2435.13257

Battaglia, L.L., Pritchett, D.W., Minchin, P.R., 2008. Evaluating Dispersal Limitation in Passive Bottomland Forest Restoration. Restor. Ecol. 16, 417-424. https://doi.org/10.1111/j.1526-100X.2007.00319.x

Bergès, L., Chevalier, R., Dumas, Y., Franc, A., Gilbert, J.-M., 2005. Sessile oak (Quercus petraea Liebl.) site index variations in relation to climate, topography and soil in even-aged high-forest stands in northern France. Ann. For. Sci. 62, 391402. https://doi.org/10.1051/forest:2005035

Bernard, M., Boulanger, V., Dupouey, J.-L., Laurent, L., Montpied, P., Morin, X., Picard, J.-F., Saïd, S., 2017. Deer browsing promotes Norway spruce at the expense of silver fir in the forest regeneration phase. For. Ecol. Manag. 400, 269277. https://doi.org/10.1016/j.foreco.2017.05.040

Bertness, M.D., Callaway, R., 1994. Positive interactions in communities. Trends Ecol. Evol. 9, 191-193. https://doi.org/10.1016/0169-5347(94)90088-4

Bobiec, A., Reif, A., Öllerer, K., 2018. Seeing the oakscape beyond the forest: a landscape approach to the oak regeneration in Europe. Landsc. Ecol. 33, 513-528. https://doi.org/10.1007/s10980-018-0619-y

Borkowski, J., Dobrowolska, D., Dąbrowski, W., Banul, R., Załuski, D., 2017. Young conifer stands form a deer browsing refuge for an oak admixture: silvicultural implications for forest regeneration under herbivore pressure. Eur. J. For. Res. 136, 787-800. https://doi.org/10.1007/s10342-017-1070-3

Boulanger, V., Baltzinger, C., Saïd, S., Ballon, P., Picard, J.-F., Dupouey, J.-L., 2009. Ranking temperate woody species along a gradient of browsing by deer. For. Ecol. Manag. 258, 1397-1406. https://doi.org/10.1016/j.foreco.2009.06.055

Burnham, K.P., Anderson, D.R., 2002. Model Selection and Multimodel Inference: A Practical Information-Theoretic Approach, 2nd ed. Springer-Verlag, New York. https://doi.org/10.1007/b97636

Clarke, A., Rothery, P., Isaac, N.J.B., 2010. Scaling of basal metabolic rate with body mass and temperature in mammals. J. Anim. Ecol. 79, 610-619. https://doi.org/10.1111/j.1365-2656.2010.01672.x

De Lombaerde, E., Verheyen, K., Van Calster, H., Baeten, L., 2019. Tree regeneration responds more to shade casting by the overstorey and competition in the understorey than to abundance per se. For. Ecol. Manag. 450, 117492. https://doi.org/10.1016/j.foreco.2019.117492

DeClerck, F.A., Barbour, M.G., Sawyer, J.O., 2006. Species richness and stand stability in conifer forests of the Sierra Nevada. Ecology 87, 2787-2799.

del Río, M., Pretzsch, H., Alberdi, I., Bielak, K., Bravo, F., Brunner, A., Condés, S., Ducey, M.J., Fonseca, T., von Lüpke, N., Pach, M., Peric, S., Perot, T., Souidi, Z., Spathelf, P., Sterba, H., Tijardovic, M., Tomé, M., Vallet, P., Bravo-Oviedo, A., 2016. Characterization of the structure, dynamics, and productivity of mixed-species stands: review and perspectives. Eur. J. For. Res. 135, 23-49. https://doi.org/10.1007/s10342-015-0927-6

Fei, S., Steiner, K.C., 2008. Relationships between advance oak regeneration and biotic and abiotic factorst. Tree Physiol. 28, 1111-1119. https://doi.org/10.1093/treephys/28.7.1111

Felton, A., Hedwall, P.O., Lindbladh, M., Nyberg, T., Felton, A.M., Holmström, E., Wallin, I., Löf, M., Brunet, J., 2016. The biodiversity contribution of wood plantations: Contrasting the bird communities of Sweden's protected and production oak forests. For. Ecol. Manag. 365, 51-60. https://doi.org/10.1016/j.foreco.2016.01.030

Forrester, D.I., 2014. The spatial and temporal dynamics of species interactions in mixed-species forests: From pattern to process. For. Ecol. Manag. 312, 282-292. https://doi.org/10.1016/j.foreco.2013.10.003

Gaudio, N., Balandier, P., Perret, S., Ginisty, C., 2011. Growth of understorey Scots pine (Pinus sylvestris L.) saplings in response to light in mixed temperate forest. For. Int. J. For. Res. 84, 187-195. https://doi.org/10.1093/forestry/cpr005

Gégout, J.-C., Coudun, C., Bailly, G., Jabiol, B., 2005. EcoPlant: A forest site database linking floristic data with soil and climate variables. J. Veg. Sci. 16, 257-260. https://doi.org/10.1111/j.1654-1103.2005.tb02363.x

Götmark, F., 2007. Careful partial harvesting in conservation stands and retention of large oaks favour oak regeneration. Biol. Conserv. 140, 349-358. https://doi.org/10.1016/j.biocon.2007.08.018

Götmark, F., Berglund, Å., Wiklander, K., 2005. Browsing damage on broadleaved trees in semi-natural temperate forest in Sweden, with a focus on oak regeneration. Scand. J. For. Res. 20, 223-234. https://doi.org/10.1080/02827580510008383 
Hagge, J., Müller, J., Bässler, C., Biebl, S.S., Brandl, R., Drexler, M., Gruppe, A., Hotes, S., Hothorn, T., Langhammer, P., Stark, H., Wirtz, R., Zimmerer, V., Mysterud, A., 2019. Deadwood retention in forests lowers short-term browsing pressure on silver fir saplings by overabundant deer. For. Ecol. Manag. 451, 117531. https://doi.org/10.1016/j.foreco.2019.117531

IGN, 2019. Le mémento de l'inventaire forestier. Inst. Natl. Inf. Géographique For

Jarvis, P.G., 1964. The Adaptability to Light Intensity of Seedlings of Quercus Petraea (Matt.) Liebl. J. Ecol. 52, 545-571. https://doi.org/10.2307/2257848

Jensen, A.M., Götmark, F., Löf, M., 2012. Shrubs protect oak seedlings against ungulate browsing in temperate broadleaved forests of conservation interest: A field experiment. For. Ecol. Manag. 266, 187-193. https://doi.org/10.1016/j.foreco.2011.11.022

Johnson, P.S., Shifley, S.R., Rogers, R., Dey, D.C., Kabrick, J.M., 2019. The Ecology and Silviculture of Oaks, 3rd Edition. CABI.

Jucker, T., Avăcăritei, D., Bărnoaiea, I., Duduman, G., Bouriaud, O., Coomes, D.A., 2016. Climate modulates the effects of tree diversity on forest productivity. J. Ecol. 104, 388-398. https://doi.org/10.1111/1365-2745.12522

Jucker, T., Bouriaud, O., Coomes, D.A., 2015. Crown plasticity enables trees to optimize canopy packing in mixed-species forests. Funct. Ecol. 29, 1078-1086. https://doi.org/10.1111/1365-2435.12428

Kelly, D.L., 2002. The regeneration of Quercus petraea (sessile oak) in southwest Ireland: a 25-year experimental study. For. Ecol. Manag. 166, 207-226. https://doi.org/10.1016/S0378-1127(01)00670-3

Klopčič, M., Simončič, T., Bončina, A., 2015. Comparison of regeneration and recruitment of shade-tolerant and lightdemanding tree species in mixed uneven-aged forests: experiences from the Dinaric region. Forestry 88, 552-563. https://doi.org/10.1093/forestry/cpv021

Kuiters, A.T., Slim, P.A., 2002. Regeneration of mixed deciduous forest in a Dutch forest-heathland, following a reduction of ungulate densities. Biol. Conserv. 105, 65-74. https://doi.org/10.1016/S0006-3207(01)00204-X

Larsen, D.R., Johnson, P.S., 1998. Linking the ecology of natural oak regeneration to silviculture. For. Ecol. Manag. 106, 1-7. https://doi.org/10.1016/S0378-1127(97)00233-8

Leuschner, C., Backes, K., Hertel, D., Schipka, F., Schmitt, U., Terborg, O., Runge, M., 2001. Drought responses at leaf, stem and fine root levels of competitive Fagus sylvatica L. and Quercus petraea (Matt.) Liebl. trees in dry and wet years. For. Ecol. Manag. 149, 33-46. https://doi.org/10.1016/S0378-1127(00)00543-0

Liang, J., Crowther, T.W., Picard, N., Wiser, S., Zhou, M., Alberti, G., Schulze, E.-D., McGuire, A.D., Bozzato, F., Pretzsch, H., de-Miguel, S., Paquette, A., Hérault, B., Scherer-Lorenzen, M., Barrett, C.B., Glick, H.B., Hengeveld, G.M., Nabuurs, G.-J., Pfautsch, S., Viana, H., Vibrans, A.C., Ammer, C., Schall, P., Verbyla, D., Tchebakova, N., Fischer, M., Watson, J.V., Chen, H.Y.H., Lei, X., Schelhaas, M.-J., Lu, H., Gianelle, D., Parfenova, E.I., Salas, C., Lee, E., Lee, B., Kim, H.S., Bruelheide, H., Coomes, D.A., Piotto, D., Sunderland, T., Schmid, B., Gourlet-Fleury, S., Sonké, B., Tavani, R., Zhu, J., Brandl, S., Vayreda, J., Kitahara, F., Searle, E.B., Neldner, V.J., Ngugi, M.R., Baraloto, C., Frizzera, L., Bałazy, R., Oleksyn, J., Zawiła-Niedźwiecki, T., Bouriaud, O., Bussotti, F., Finér, L., Jaroszewicz, B., Jucker, T., Valladares, F., Jagodzinski, A.M., Peri, P.L., Gonmadje, C., Marthy, W., O’Brien, T., Martin, E.H., Marshall, A.R., Rovero, F., Bitariho, R., Niklaus, P.A., Alvarez-Loayza, P., Chamuya, N., Valencia, R., Mortier, F., Wortel, V., Engone-Obiang, N.L., Ferreira, L.V., Odeke, D.E., Vasquez, R.M., Lewis, S.L., Reich, P.B., 2016. Positive biodiversity-productivity relationship predominant in global forests. Science 354 https://doi.org/10.1126/science.aaf8957

Ligot, G., Ameztegui, A., Courbaud, B., Coll, L., Kneeshaw, D., 2016. Tree light capture and spatial variability of understory light increase with species mixing and tree size heterogeneity. Can. J. For. Res. 46, 968-977. https://doi.org/10.1139/cjfr2016-0061

Ligot, G., Balandier, P., Fayolle, A., Lejeune, P., Claessens, H., 2013. Height competition between Quercus petraea and Fagus sylvatica natural regeneration in mixed and uneven-aged stands. For. Ecol. Manag. 304, 391-398. https://doi.org/10.1016/j.foreco.2013.05.050

Löf, M., Brunet, J., Filyushkina, A., Lindbladh, M., Skovsgaard, J.P., Felton, A., 2016. Management of oak forests: striking a balance between timber production, biodiversity and cultural services. Int. J. Biodivers. Sci. Ecosyst. Serv. Manag. 12, 59-73. https://doi.org/10.1080/21513732.2015.1120780

Loreau, M., de Mazancourt, C., 2013. Biodiversity and ecosystem stability: a synthesis of underlying mechanisms. Ecol. Lett. 16, 106-115. https://doi.org/10.1111/ele.12073

Mårell, A., Hamard, J.-P., Pérot, T., Perret, S., Korboulewsky, N., 2018. The effect of deer browsing and understory light availability on stump mortality and sprout growth capacity in sessile oak. For. Ecol. Manag. 430, 134-142. https://doi.org/10.1016/j.foreco.2018.08.015

Messier, C., Parent, S., Bergeron, Y., 1998. Effects of Overstory and Understory Vegetation on the Understory Light Environment in Mixed Boreal Forests. J. Veg. Sci. 9, 511-520. https://doi.org/10.2307/3237266

Milberg, P., Bergman, K.-O., Sancak, K., Jansson, N., 2016. Assemblages of saproxylic beetles on large downed trunks of oak. Ecol. Evol. 6, 1614-1625. https://doi.org/10.1002/ece3.1935

Miller, B.F., Campbell, T.A., Laseter, B.R., Ford, W.M., Miller, K.V., 2009. White-tailed deer herbivory and timber harvesting rates: Implications for regeneration success. For. Ecol. Manag. 258, 1067-1072. https://doi.org/10.1016/.j.foreco.2009.05.025

Muscolo, A., Bagnato, S., Sidari, M., Mercurio, R., 2014. A review of the roles of forest canopy gaps. J. For. Res. 25, 725-736. https://doi.org/10.1007/s11676-014-0521-7

Niinemets, Ü., 2010. A review of light interception in plant stands from leaf to canopy in different plant functional types and in species with varying shade tolerance. Ecol. Res. 25, 693-714. https://doi.org/10.1007/s11284-010-0712-4

Niinemets, Ü., Valladares, F., 2006. Tolerance to shade, drought, and waterlogging of temperate northern hemisphere trees and shrubs. Ecol. Monogr. 76, 521-547. https://doi.org/10.1890/0012-9615(2006)076[0521:TTSDAW]2.0.CO;2

Perot, T., Mårell, A., Korboulewsky, N., Seigner, V., Balandier, P., 2017. Modeling and predicting solar radiation transmittance in mixed forests at a within-stand scale from tree species basal area. For. Ecol. Manag. 390, 127-136. https://doi.org/10.1016/j.foreco.2017.01.023

Perot, T., Picard, N., 2012. Mixture enhances productivity in a two-species forest: evidence from a modeling approach. Ecol. Res. 27, 83-94. https://doi.org/10.1007/s11284-011-0873-9

Petersson, L.K., Milberg, P., Bergstedt, J., Dahlgren, J., Felton, A.M., Götmark, F., Salk, C., Löf, M., 2019. Changing land use and increasing abundance of deer cause natural regeneration failure of oaks: Six decades of landscape-scale evidence. For. Ecol. Manag. 444, 299-307. https://doi.org/10.1016/j.foreco.2019.04.037 
Piedallu, C., Gégout, J.-C., 2007. Multiscale computation of solar radiation for predictive vegetation modelling. Ann. For. Sci. 64, 899-909. https://doi.org/10.1051/forest:2007072

Piedallu, C., Gégout, J.-C., Perez, V., Lebourgeois, F., 2013. Soil water balance performs better than climatic water variables in tree species distribution modelling. Glob. Ecol. Biogeogr. 22, 470-482. https://doi.org/10.1111/geb.12012

Piedallu, C., Noémie, P., Ary, B., Lucie, D., Julien, F., 2018. Estimer le réservoir en eau des sols Quelles fonctions de pédotransfert le forestier doit-il utiliser? For.-Entrep. 242, 28-32.

Pinheiro, J., Bates, D., 2000. Mixed-Effects Models in S and S-PLUS, Statistics and Computing. Springer-Verlag, New York. https://doi.org/10.1007/b98882

Pinheiro, J., Bates, D., DebRoy, S., Sarkar, D., Heisterkamp, S., Van Willigen, B., Maintainer, R., 2017. Package 'nlme.' Linear Nonlinear Mix. Eff. Models Version 3.

Pretzsch, H., Schütze, G., 2009. Transgressive overyielding in mixed compared with pure stands of Norway spruce and European beech in Central Europe: evidence on stand level and explanation on individual tree level. Eur. J. For. Res. 128, 183-204. https://doi.org/10.1007/s10342-008-0215-9

Purves, D.W., Lichstein, J.W., Pacala, S.W., 2007. Crown Plasticity and Competition for Canopy Space: A New Spatially Implicit Model Parameterized for 250 North American Tree Species. PLOS ONE 2, e870. https://doi.org/10.1371/journal.pone.0000870

R Core Team, 2019. R: A Language and Environment for Statistical Computing. R Foundation for Statistical Computing, Vienna, Austria.

Ramirez, J.I., Jansen, P.A., Poorter, L., 2018. Effects of wild ungulates on the regeneration, structure and functioning of temperate forests: A semi-quantitative review. For. Ecol. Manag. 424, 406-419. https://doi.org/10.1016/j.foreco.2018.05.016

Rodríguez-Calcerrada, J., Pardos, J.A., Gil, L., Reich, P.B., Aranda, I., 2008. Light response in seedlings of a temperate (Quercus petraea) and a sub-Mediterranean species (Quercus pyrenaica): contrasting ecological strategies as potential keys to regeneration performance in mixed marginal populations. Plant Ecol. 195, 273-285. https://doi.org/10.1007/s11258-007-9329-2

Thompson, I., Mackey, B., McNulty, S., Mosseler, A., 2009. Forest Resilience, Biodiversity, and Climate Change. Secr. Conv. Biol. Divers. Montr. 43, 1-67.

Tinya, F., Márialigeti, S., Bidló, A., Ódor, P., 2019. Environmental drivers of the forest regeneration in temperate mixed forests. For. Ecol. Manag. 433, 720-728. https://doi.org/10.1016/j.foreco.2018.11.051

Toïgo, M., Perot, T., Courbaud, B., Castagneyrol, B., Gégout, J.-C., Longuetaud, F., Jactel, H., Vallet, P., 2018. Difference in shade tolerance drives the mixture effect on oak productivity. J. Ecol. 106, 1073-1082. https://doi.org/10.1111/13652745.12811

Toïgo, M., Vallet, P., Perot, T., Bontemps, J.-D., Piedallu, C., Courbaud, B., 2015a. Overyielding in mixed forests decreases with site productivity. J. Ecol. 103, 502-512. https://doi.org/10.1111/1365-2745.12353

Toïgo, M., Vallet, P., Tuilleras, V., Lebourgeois, F., Rozenberg, P., Perret, S., Courbaud, B., Perot, T., 2015b. Species mixture increases the effect of drought on tree ring density, but not on ring width, in Quercus petraea-Pinus sylvestris stands. For. Ecol. Manag. 345, 73-82. https://doi.org/10.1016/j.foreco.2015.02.019

Vallet, P., Pérot, T., 2011. Silver fir stand productivity is enhanced when mixed with Norway spruce: evidence based on largescale inventory data and a generic modelling approach: Silver fir stand productivity is enhanced when mixed with Norway spruce. J. Veg. Sci. 22, 932-942. https://doi.org/10.1111/j.1654-1103.2011.01288.x

Van Couwenberghe, R., Gégout, J.-C., Lacombe, E., Collet, C., 2013. Light and competition gradients fail to explain the coexistence of shade-tolerant Fagus sylvatica and shade-intermediate Quercus petraea seedlings. Ann. Bot. 112, 1421-1430. https://doi.org/10.1093/aob/mct200

Ward, J.S., Williams, S.C., Linske, M.A., 2018. Influence of invasive shrubs and deer browsing on regeneration in temperate deciduous forests. Can. J. For. Res. 48, 58-67. https://doi.org/10.1139/cjfr-2017-0208

White, C.R., Seymour, R.S., 2005. Allometric scaling of mammalian metabolism. J. Exp. Biol. 208, 1611-1619. https://doi.org/10.1242/jeb.01501

Wright, R.E., 1995. Logistic regression, in: Reading and Understanding Multivariate Statistics. American Psychological Association, Washington, DC, US, pp. 217-244.

Yachi, S., Loreau, M., 1999. Biodiversity and ecosystem productivity in a fluctuating environment: The insurance hypothesis. Proc. Natl. Acad. Sci. U. S. A. 96, 1463-1468.

Zhang, Y., Chen, H.Y.H., Reich, P.B., 2012. Forest productivity increases with evenness, species richness and trait variation: a global meta-analysis. J. Ecol. 100, 742-749. https://doi.org/10.1111/j.1365-2745.2011.01944.x 


\section{Appendix}

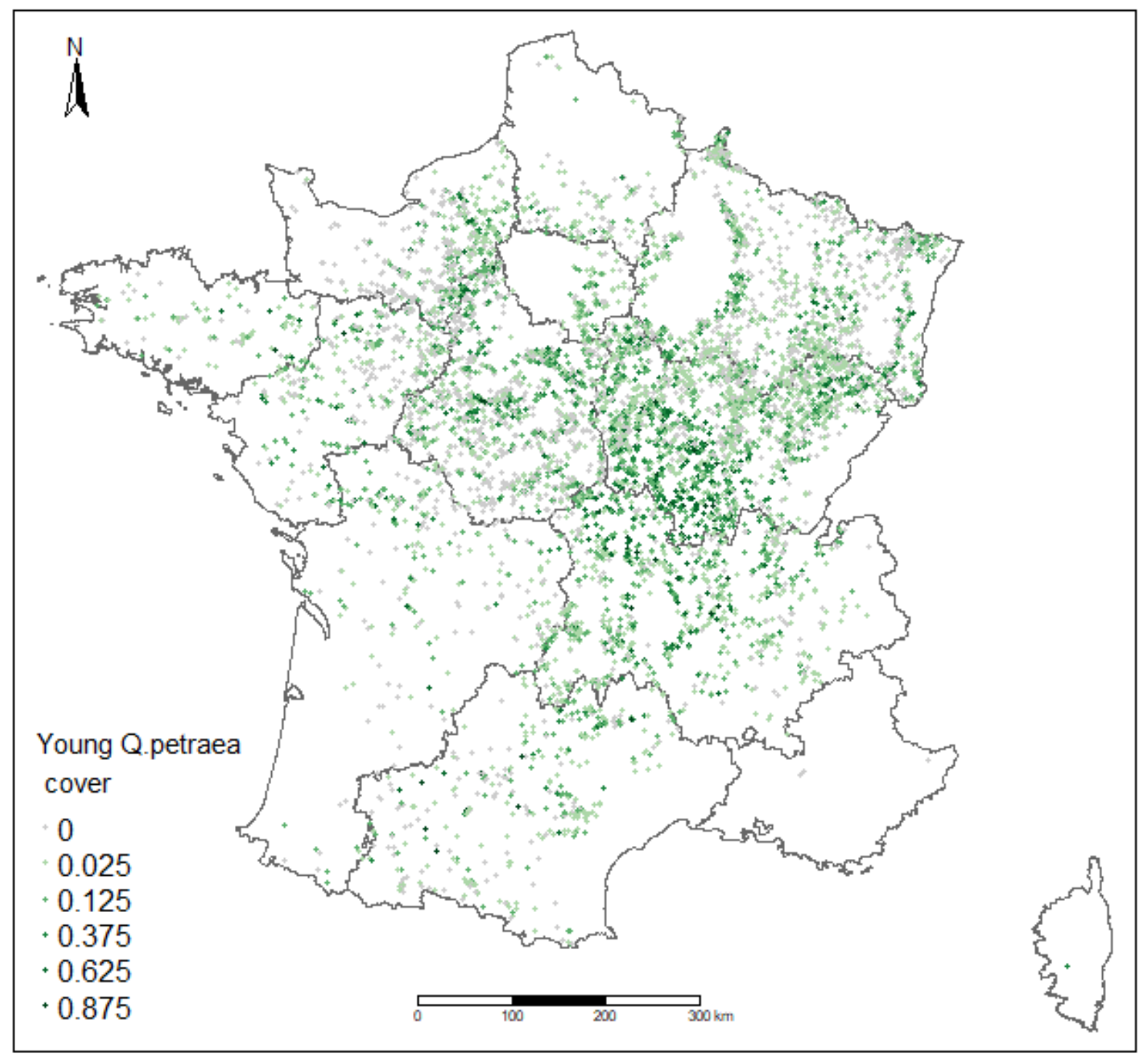

Figure A.1: Map of the cover percentage of regenerating Q. petraea of the final selection of plots 
Table A.1: Mean, standard deviation, range and the selected form of fitting procedure for the continuous variables in the regeneration model prior to centering and scaling. Note that we rescaled the variables according to the equation $X_{\text {unscaled }}=X_{\text {scaled }}{ }^{*}$ Standard deviation + Mean

\begin{tabular}{|l|l|l|l|c|}
\hline Variable & Mean & $\begin{array}{l}\text { Standard } \\
\text { deviation }\end{array}$ & Range & Selected form \\
\hline Total canopy cover $(\%)$ & 85.09 & 16.86 & $9-100$ & $a_{n} * X_{n}+a_{n 2} * X_{n}{ }^{2}$ \\
\hline $\mathrm{PET}_{7}(\mathrm{~mm})$ & 125.9 & 5.851 & $107.5-149.2$ & $a_{n} * X_{n}+a_{n 2} * X_{n}{ }^{2}$ \\
\hline Tmax $_{12}\left({ }^{\circ} \mathrm{C}\right)$ & 6.612 & 1.164 & $2.821-11.33$ & $a_{n} * X_{n}+a_{n 2} * X_{n}{ }^{2}$ \\
\hline pH & 5.209 & 0.9031 & $3.17-7.907$ & $a_{n} * X_{n}+a_{n 2} * X_{n}{ }^{2}$ \\
\hline Herbivory index & 49.8 & 29.04 & $5.518-166.8$ & $a_{n 1} * \exp \left(a_{n 2} * X_{n}\right)$ \\
\hline Rocky outcrop (\%/10) & 0.3047 & 1.124 & $0-10$ & $a_{n} * X_{n}$ \\
\hline North-South exposure & -0.007146 & 0.4973 & $-1-1$ & $a_{n} * X_{n}$ \\
\hline East-West exposure & -0.0198 & 0.504 & $-1-1$ & $a_{n} * X_{n}$ \\
\hline
\end{tabular}

Figure A.2 (next page): Q. petraea regeneration cover as a function of an environmental parameter in the dataset (grey points), smoothed by a LOESS curve (in red) and predicted by the environmental function of the model (blue line) while the other parameters were set either to the mean or to the Booleans reference level for a pure stand. $(A)$ for total canopy cover, $(B)$ for herbivory index, (C) for mean evapotranspiration potential in July, $(D)$ for mean December maximal temperature, and (E) for soil $\mathrm{pH}$. 

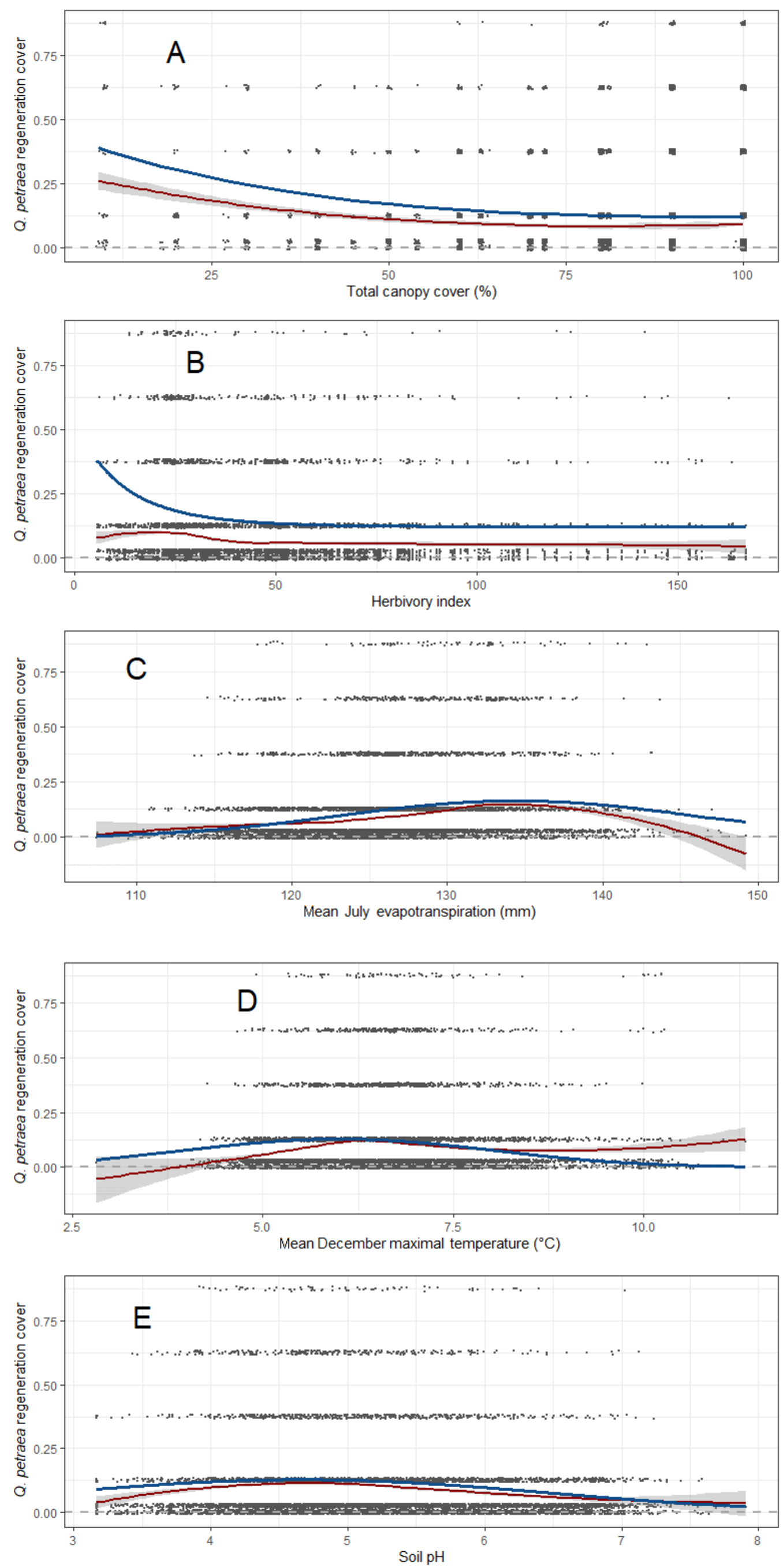